\title{
Penegakan Hukum Administrasi Akibat Pembakaran Hutan Dan Lahan Oleh Badan Hukum Perdata di Kabupaten Muaro Jambi
}

\author{
Fitria \\ Fakultas Hukum Universitas Jambi \\ Kampus Pinang Masak-Mendalo indah, Jambi 36361
}

Email :fit3_zen@Yahoo.com

\begin{abstract}
ABSTRAK
Penelitian ini bertujuan untuk: 1.mekanisme Penegakan Hukum administrasi akibat Pembakaran Hutan dan Lahan Oleh Badan Hukum Perdata di Kabupaten Muaro Jambi. 2. Untuk mengetahui dan menganalis menganalisis Upaya Penanggulangan akibat Pembakaran Hutan dan Lahan oleh Badan Hukum Perdata di Kabupaten Muaro Jambi. Pendekatan yang digunakan bersifat yuridis empiris, secara yuridis melihat peraturan perundang-undangan yang mengatur tentang pengawasan terhadap Penegakan Hukum Adminsitrasi akibat pembakaran hutan dan lahan, secara empiris dengan melihat apakah ketentuan pengawasan terhadap penegakan hukum administrasi akibat pembakaran hutan dan lahan oleh badan hukum perdata tersebut diterapkan di Kabupaten Muaro Jambi.Di dalam Undang-Undang Kehutanan telah diatur tentang larangan membakar hutan seperti yang terdapat dalam Pasal 50 ayat (3) huruf d yang menyatakan "setiap orang dilarang membakar hutan", Pasal 69 ayat (1) huruf a dan h UU-PPLH menyatakan, Setiap orang dilarang: "melakukan perbuatan yang mengakibatkan pencemaran dan/atau perusakan lingkungan hidup; dan melakukan pembukaan lahan dengan cara membakar. Dari Penelitian ini di harapkan pelanggaran yang dilakukan pemegang izin usaha dibidang Perkebunan yang telah melakukan pembakaran hutan dan lahan di Kabupaten Muaro Jambi patut dikenakan sanksi yang tegas. Sanksi administrasi merupakan salah satu instrumen hukum dalam menjaga kelestarian lingkungan. Tetapi dalam pelaksanaannya sering kali kita melihat sulitnya menerapkan sanksi terhadap pelanggaran-pelanggaran yang dilakukan oleh pemegang izin Perkebunan karena masalah pembuktian.Apabila penerapan sanksi administrasi tidak diterapkan, maka kerusakan terhadap lingkungan akan semakin meluas dan masalah pembakaran lahan tidak akan kunjung selesai. Oleh sebab itu, pemerintah Kabupaten Muaro Jambi di tuntut untuk mengusut kasus pembakaran lahan secara serius dan menerapkan sanksi sesuai dengan peraturan perundang-undangan yang berlaku.
\end{abstract}

Kata kunci: Penegakan Hukum Administrasi, Pembakaran Hutan dan Lahan, Badan Hukum Perdata.

\section{PENDAHULUAN}

\subsection{Latar Belakang Masalah}

Undang-Undang Nomor 41 Tahun 1999 mengamanatkan bahwa Penyelenggaraan kehutanan bertujuan untuk sebesar-besar kemakmuran rakyat yang berkeadilan dan berkelanjutan. Undang-Undang Nomor 32 Tahun 2009 Tentang Perlindungan dan pengelolaan Lingkungan Hidup bertujuan melindungi wilayah Negara Kesatuan Republik Indonesia dari pencemaran dan/atau kerusakan lingkungan hidup, selanjutnya amanat dari Undang-Undang Nomor 39 Tahun 2014 Tentang Perkebunan bertujuan meningkatkan kesejahteraan rakyat dan kemakmuran rakyat.

Pasal 88 Undang-Undang Nomor 32 Tahun 2009 Tentang Perlindungan dan Pengelolaan Lingkungan Hidup menjelaskan:

"Setiap orang yang tindakannya, usahanya, dan/atau kegiatannya menggunakan B3, menghasilkan dan/atau mengelola limbah B3, dan/atau yang menimbulkan ancaman serius terhadap lingkungan hidup bertanggung jawab mutlak atas kerugian yang terjadi tanpa perlu pembuktian unsur kesalahan".

Artinya, jika terjadi kebakaran hutan dan lahan di areal HPH yang dikuasai oleh suatu perusahaan, maka secara otomatis langsung perusahaan atau badan hukum itulah yang harus bertanggung jawab, tanpa harus melihat kesalahan, artinya apakah kebakaran yang terjadi itu 
dilakukan dengan sengaja atau tidak sengaja/kealpaan maka pelaku pembakaran sudah dapat dijatuhi sanksi.

Selama ini pengelolaan hutan khususnya perlindungan hutan masih berpedoman pada UU Kehutanan serta undang-undang terkait dan peraturan pemerintah di bawahnya yang merupakan peraturan pelaksananya. Di mana, pengeloaan hutan dibagi kewenangannya antara pemerintah pusat, pemerintah daerah provinsi dan pemerintah daerah kabupaten. Pembagian kewenangan tersebut dilaksanakan melalui pembagian urusan yang diatur dalam UndangUndang Nomor 32 tahun 2004 tantang Pemerintahan Daerah serta peraturan pelaksananya yang kemudian diubah ke dalam Undang-Undang Nomor 23 tahun 2014 tentang Pemerintahan Daerah.

Dalam Undang-Undang Nomor 23 tahun 2014 saat ini terdapat perubahan yang sangat mendasar dari undang-undang pemerintahan daerah yang sebelumnya. Perubahan tersebut berkaitan dengan dialihkannya kewenangan daerah kabupaten/kota ke daerah provinsi di beberapa sektor salah satunya sektor kehutanan. Penyelenggaraan urusan pemerintahan di bidang kehutanan, kelautan, serta energi dan sumber daya mineral dibagi antara pemerintah pusat dan pemerintah daerah provinsi. Urusan pemerintahan bidang kehutanan yang berkaitan dengan pengelolaan taman hutan raya (TAHURA) kabupaten/kota menjadi kewenangan pemerintah daerah kabupaten/kota.

Pada lampiran Undang-Undang Nomor 23 tahun 2014 halaman 116, pembagian urusan pemerintahan di bidang kehutanan menghapuskan kegiatan perlindungan hutan di tingkat kabupaten/kota. Adapun urusan bidang kehutanan, yang sebelumnya menjadi wewenang kabupaten/kota, hampir semuanya ditarik menjadi kewenangan daerah provinsi. Hanya pengelolaan TAHURA kabupaten/kota yang menjadi kewenangan pemerintah daerah kabupaten/kota.

Jika mengacu kepada Undang-Undang Nomor 23 tahun 2014 maka tidak ada lagi perangkat perlindungan di daerah kabupaten/kota, urusan perlindungan hutan semuanya diserahkan ke pemerintah daerah provinsi selaku pemegang urusan kehutanan di daerah. Sementara, kegiatan perlindungan hutan ini tidak hanya mencakup kawasan konservasi saja, tetapi juga mencakup kawasan hutan lindung, kawasan hutan produksi dan kawasan hutan lainnya.

Di lain pihak, masalah perlindungan hutan merupakan masalah yang cukup kompleks dan dinamis. Dengan adanya perkembangan di berbagai bidang dan perubahan-perubahan di lapangan, maka terjadi pula perkembangan permasalahan perlindungan hutan. Seperti berubahnya fungsi hutan yang dikarenakan perladangan berpindah, peladangan liar, pencurian kayu, perambahan kawasan hutan yang dilakukan oleh kelompok-kelompok masyarakat yang berdiam di sekitar maupun di dalam kawasan hutan dan penggunaan kawasan hutan untuk pembangunan di luar sektor kehutanan.

Akan tetapi melihat berbagai pelanggaran yang dilakukan pemegang izin usaha dibidang Perkebunan yang telah melakukan pembakaran hutan dan lahan di Kabupaten Muaro Jambi patut dikenakan sanksi yang tegas. Sanksi administrasi merupakan salah satu instrumen hukum dalam menjaga kelestarian lingkungan. Tetapi dalam pelaksanaannya sering kali kita melihat sulitnya menerapkan sanksi terhadap pelanggaran-pelanggaran yang dilakukan oleh pemegang izin Perkebunan karena masalah pembuktian.

Apabila penerapan sanksi administrasi tidak diterapkan, maka kerusakan terhadap lingkungan akan semakin meluas dan masalah pembakaran lahan tidak akan kunjung selesai. Oleh sebab itu, pemerintah Kabupaten Muaro Jambi di tuntut untuk mengusut kasus pembakaran lahan secara serius dan menerapkan sanksi sesuai dengan peraturan perundangundangan yang berlaku.

Sanksi-sanksi hukum administrasi yang khas, antara lain:

a. Bestuursdwang (paksaan pemerintahan); 
b. Penarikan kembali keputusan (ketetapan) yang menguntungkan (izin, pembayaran, subsidi);

c. Pengenaan denda administratif;

d. Pengenaan uang paksa oleh pemerintah (dwangsom). ${ }^{1}$

Berdasarkan latar belakang dari permasalahan yang telah diuraikan di atas, maka penulis merasa tertarik untuk melakukan penelitian dengan judul "PENEGAKAN HUKUM ADMINISTRASI AKIBAT PEMBAKARAN HUTAN DAN LAHAN OLEH BADAN HUKUM PERDATA DI KABUPATEN MUARO JAMBI."

\section{PERUMUSAN MASALAH}

Berdasarkan uraian latar belakang tersebut, maka penulis membatasi permasalahan dengan rumusan sebagai berikut:

1. Bagaimana mekanisme penegakan hukum administrasi Akibat Pembakaran Hutan dan Lahan oleh Badan Hukum Perdata di Kabupaten Muaro Jambi ?

2. Bagaimana Upaya Penanggulangan Akibat Pembakaran Hutan dan Lahan oleh Badan Hukum Perdata di Kabupaten Muaro Jambi?

\section{TINJAUAN PUSTAKA}

\subsection{Penegakan Hukum Administrasi Negara}

Menurut P. Nicolai dan kawan-kawan, Sarana penegakan hukum administrasi berisi (1) Pengawasan bahwa organ pemerntah dapat melaksanakan ketaatan pada atau berdasarkan undang-undang yang ditetapkan secara tertulis dan pengawasan terhadap keputusan yang meletakan kewajiban kepada individu dan (2) penerapan kewenangan sanksi Pemerintah. Pendapat yang dikemukakan Nicolai Hamper senada dengan Ten Berg seperti yang dikutip Philipus M. Hadjon, yang menyebutkan bahwa instrument penegakan hukum administrasi meliputi pengawasan dan penegakan sanksi. Pengawasan merupakan langkah preventif untuk memaksakan kepatuhan sedangkan sanksi merupakan langkah represif untuk memaksakan kepatuhan.

Pengawasan terhadap tindakan pemerintah dimaksudkan agar menjalankan aktivitasnya sesuai dengan norma-norma hukum, sebagai upaya preventif, dan juga dimaksudkan untuk mengembalikan pada situasi sebelum terjadinya pelanggaran norma-norma hukum, sebagai suatu upaya represif. Disamping itu yang paling penting adalah pengawasan ini diupayakan dalam rangka memberikan pertlindungan hkum bagi rakyat. Telah disebutkan bahwa sarana penegakan hukum itu disamping pengawasan, adalah sanksi. Sanksi merupakan bagian penting dalam setiap peraturan perundang-undangan, bahkan menurut J.B.J.M ten Berg menyebutkan bahwa sanksi merupakan inti dari penegakan hukum administrasi.

Dalam hukum Administrasi Negara, penggunaan sanksi administrasi merupakan penerapan kewenangan pemerintahan di mana kewenangan berasal dari aturan hukum administrasi tertulis dan tidak tertulis. Sanksi dalam Hukum Administrasi yaitu Alat kekuasaan yang bersifat hukum public yang dapat digunakan oleh pemerintah sebagai reaksi atas ketidakpatuhan terhadap kewajiban yang terdapat dalam norma hukum administrasi.Izin tidak sama dengan pem biaran. Kalau ada suatu aktifitas dari anggota masyarakat yang sebenarnya dilarang oleh peraturan perundang-undangan yang berlaku, tetapi ternyata tidak dilakukan penindakan oleh aparatur yang berwenang, pembiaran seperti itu bukan berarti

\footnotetext{
${ }^{1}$ Philipus M. Hadjon, et. al, Pengantar Hukum Administrasi Indonesia, Gadjah Mada University Press, Yogyakarta, 1993, hal. 241.
} 
diizinkan. Dapat dikatakan izin harus ada keputusan konstitutif dari aparatur yang berwenang menerbitkan izin.

\subsection{Kebakaran Hutan dan Lahan Perkebunan}

Kebakaran hutan dibedakan dengan kebakaran lahan. Kebakaran hutan adalah kebakaran yang terjadi di dalam kawasan hutan, sedangkan kebakaran lahan terjadi di luar kawasan hutan. Kebakaran hutan dan lahan disebabkan oleh faktor kesengajaan manusia oleh beberapa kegiatan, seperti ladang berpindah, Perkebunan Inti Rakyat (PIR), Hutan Tanaman Industri (HTI), penyiapan lahan untuk ternak sapi.

Kebakaran lahan adalah perubahan langsung atau tidak langsung terhadap sifat fisik dan atau hayatinya yang menyebabkan kurang berfungsinya lahan dalam menunjang kehidupan yang berkelanjutan sebagai akibat dari penggunaan api yang tidak terkendali maupun faktor alam yang dapat mengakibatkan terjadinya kebakaran lahan. $^{2}$

1. Faktor-faktor yang menyebabkan kebakaran lahan
a. Bahan bakar
b. Cuaca
c. Waktu
d. Topografi

2. Tipe-tipe kebakaran
a. Kebakaran Bawah (Ground Fire)
b. Kebakaran Permukaan (Surface Fire).
c. Kebakaran Tajuk (Crown Fire).

3. Dampak kebakaran hutan dan lahan
a. Dampak langsung
b. Dampak ekologis
c. Dampak Terhadap Sosial Ekonomi
d. Dampak Terhadap Lingkungan
e. Dampak kesehatan

\section{TUJUAN DAN MANFAAT PENELITIAN}

\subsection{Tujuan Penelitian}

Sesuai dengan permasalahan yang dirumuskan di atas, maka tujuan yang akan dicapai dari penelitian ini adalah sebagai berikut:

a. Tujuan penelitian

1) Untuk mengetahui dan menganalisis mekanisme Penegakan Hukum administrasi Akibat Pembakaran Hutan dan Lahan oleh Badan Hukum Perdata di Kabupaten Muaro Jambi

2) Untuk mengetahui dan menganalisis Upaya Penanggulangan Akibat Pembakaran Hutan dan Lahan oleh Badan Hukum Perdata di Kabupaten Muaro Jambi.

b. Kontribusi Penelitian

Sesuai dengan tujuan penelitian, maka kontribusi yang diharapkan dapat diperoleh dari penelitian ini adalah sebagai berikut:

\footnotetext{
${ }^{2}$ http://trishadennis.blogspot.co.id/2012/10/kebakaran-hutan.html
} 


\section{Secara teoritis/ akademik}

a. Dapat menambah ilmu pengetahuan pembaca, khususnya bagi peneliti sendiri dalam mengembangkan kerangka-kerangka pemikiran dibidang hukum tentang Penegakan Hukum Administrasi Akibat Pembakaran Hutan dan Lahan oleh Badan Hukum Perdata di Kabupaten Muaro Jambi

b. Dapat memudahkan untuk melakukan penelitian lebih lanjut dengan ruang lingkup yang lebih mendalam dibidang aspek hukum administrasi terkait Hukum Lingkungan

\section{Secara praktis}

a. Hasil penelitian ini nantinya dapat dijadikan bahan masukan bagi para pembuat peraturan perundang-undangan terhadap Penegakan Hukum Administrasi Akibat Pembakaran Hutan dan Lahan oleh Badan Hukum Perdata di Kabupaten Muaro Jambi

b. Hasil penelitian ini diharapkan juga nantinya dapat dijadikan masukan bagi pemerintah dan para praktisi perlindungan hukum terkait bagaimana Penegakan Hukum Administrasi Akibat Pembakaran Hutan dan Lahan di Kabupaten Muaro Jambi

\section{METODE PENELITIAN}

\subsection{Bentuk dan spesifikasi dan Pendekatan Penelitian}

1. Spesifikasi Penelitian

Penelitian ini tergolong deskriptif, yaitu penulis menggambarkan secara rinci tentang Penegakan Hukum administrasi Akibat Pembakaran Hutan dan Lahan Oleh Badan Hukum Perdata di Kabupaten Muaro Jambi.

2. Pendekatan penelitian

Untuk tipe penelitian yuridis empiris.

Pendekatan yang digunakan bersifat yuridis empiris, secara yuridis melihat peraturan perundang-undangan yang mengatur tentang pengawasan terhadap Penegakan Hukum Adminsitrasi Akibat pembakaran hutan dan lahan oleh badan Hukum Perdata, secara empiris dengan melihat apakah ketentuan pengawasan terhadap penegakan hukum administrasi Akibat pembakaran hutan dan lahan oleh Badan hukum Perdata tersebut diterapkan di Kabupaten Muaro Jambi.

3. Sumber Data.

Sumber data dalam penelitian ini diperoleh melalui:

a. Penelitian Kepustakaan (Library Research)

4. Alat Pengumpulan Data
a. Wawancara
b. Studi dokumen

6. Analisis Data

Setelah data berhasil dikumpulkan dan diolah dengan baik, kemudian data tersebut dianalisis secara kualitatif. Analisis berarti data yang ada dikelompokkan menurut permasalahan yang diteliti, kemudian diuraikan dalam bentuk kalimat sehingga nantinya dapat menjawab permasalahan yang diajukan, kemudian diambil kesimpulan yang relevan dengan penelitian ini. 


\section{HASIL DAN PEMBAHASAN}

\section{Mekanisme Penegakan Hukum Administrasi Akibat Pembakaran Hutan dan Lahan oleh Badan Hukum Perdata di Kabupaten Muaro Jambi}

Faktor-faktor yang menyebabkan kebakaran lahan perkebunan menurut Junaidi, selaku Kepala Seksi Konservasi dan Rehabilitasi Lahan Dinas Perkebunan Provinsi Jambi menyebutkan:

"Faktor penyebab kebakaran lahan yaitu: pertama, faktor alam itu sendiri. Maksudnya karena musim kemarau yang panjang sehingga menyebabkan kekeringan yang memudahkan terjadinya kebakaran. Sedangkan di lahan gambut sebenarnya bukan hanya faktor kesengajaan, akan tetapi karena adanya gesekan yang terjadi di bawah permukaan yang menyebabkan terciptanya percikan api. Kedua, faktor manusia itu sendiri yang dengan sengaja membakar lahan untuk penyiapan lahan produksi". 3

Pembakaran hutan dan lahan merupakan perbuatan yang dilarang karena selain melanggar Pasal 50 ayat 3 huruf (d) Undang-Undang Nomor 41 Tahun 1999 jo UndangUndang Nomor 19 Tahun 2004 tentang Kehutanan, Pasal 69 ayat 1 huruf d Undang-Undang Nomor 32 Tahun 2009 tentang Perlindungan dan Pengelolaan Lingkungan Hidup, Pasal 56 ayat 1 Undang-Undang Nomor 39 Tahun 2014 tentang Perkebunan juga melanggar Pasal 11 Peraturan Pemerintah Nomor 4 Tahun 2001 Tentang Pengendalian Kerusakan dan atau Pencemaran Lingkungan Hidup Yang Berkaitan Dengan Kebakaran Hutan dan atau Lahan.

Berdasarkan data estimasi Perhitungan Kerugian Dampak Kebakaran Kebun di Kabupaten Muaro Jambi Dari Bulan Januari S/D Oktober 2015 yang terjadi di lokasi lahan perkebunan PT. Puri Hijau Lestari dengan total luas kebakaran $70 \mathrm{Ha}$ menimbulkan estimasi kerugian sebesar Rp.2.456.160.000,- (Dua Milyar Empat Ratus Lima Puluh Enam Juta Seratus Enam Puluh Ribu Rupiah), PT. Citra Quinta dengan total luas kebakaran $30 \mathrm{Ha}$ menimbulkan estimasi kerugian sebesar Rp.1.052.640.000.- (Satu Milyar Lima Puluh Dua Juta Enam Ratus Empat Puluh Ribu Rupiah), PT. Bahari Gembira Ria dengan total luas kebakaran 25 Ha menimbulkan estimasi kerugian sebesar Rp.877.200.000,- (Delapan Ratus Tujuh Puluh Tujuh Juta Dua Ratus Ribu Rupiah), PT. Ricky Mas Jaya dengan total luas Kebakaran 35 Ha menimbulkan estimasi kerugian sebesar Rp.1.219.050.000,- (Satu Milyar Dua Ratus Sembilan Belas Juta Lima Puluh Ribu Rupiah), PT. Bara Eka Prima dengan total luas kebakaran 300 Ha menimbulkan estimasi kerugian sebesar Rp.10.449.000.000,- (Sepuluh Milyar Empat Ratus Empat Puluh Sembilan Juta Rupiah), PT. Bukit Sawit Sejahtera dengan total luas kebakaran 60 Ha menimbulkan estimasi kerugian sebesar Rp.2.089.800.000,- (Dua Milyar Delapan Puluh Sembilan Juta Delapan Ratus Ribu Rupiah), Pt. Ricky Kurniawan Kertapers dengan total luas kebakaran 175 Ha menimbulkan estimasi kerugian sebesar Rp.6.140.400.000,- (Enam Milyar Seratus Empat Puluh Juta Empat Ratus Ribu Rupiah). PT. Bumi Andalas dengan total luas kebakaran 40 Ha menimbulkan estimai kerugian sebesar Rp.1.393.200.000,- (Satu Milyar Tiga Ratus Sembilan Puluh Tiga Juta Dua ratus Ribu Rupiah), PT. Agung Perkasa Sawit dengan total luas kebakaran 50 Ha menimbulkan estimasi kerugian sebesar Rp.1.741.500.000,- (Satu Milyar Tujuh Ratus Empat Puluh Satu Juta Lima Ratus Ribu Rupiah), PT. Brahma Bhina Bakti dengan total luas kebakaran $45 \mathrm{Ha}$ menimbulkan estimasi kerugian sebesar Rp.1.578.960.000,- (Satu Milyar Lima Ratus Tujuh Puluh Delapan Juta Sembilan Ratus Enam Puluh Ribu Rupiah), PT. Petaling Mandraguna dengan total luas kebakaran $30 \mathrm{Ha}$ menimbulkan estimasi kerugian sebesar Rp.1.052.640.000,- (Satu Milyar Lima Puluh Dua Juta Enam Ratus Empat Puluh Ribu Rupiah), PT. Makmur Bina Bestari dengan total luas kebakaran 30 Ha menimbulkan estimasi

${ }^{3}$ Wawancara dengan Junaidi, Kepala Seksi Konservasi dan Rehabilitasi Lahan Dinas Perkebunan Provinsi Jambi. 
kerugian sebesar Rp.1.052.640.000,- (Satu Milyar Lima Puluh Dua Juta Enam Ratus Empat Puluh Ribu Rupiah), PT. Era Sakti W dengan total luas kebakaran 30 Ha menimbulkan estimasi kerugian sebesar Rp.1.052.640.000,- (Satu Milyar Lima Puluh Dua Juta Enam Ratus Empat Puluh Ribu Rupiah), PT. BAM dengan total luas kebakaran 3 Ha menimbulkan estimasi kerugian sebesar Rp.105.264.000,- (Seratus Lima Juta Dua Ratus Enam Puluh Empat Ribu Rupiah), PT. Jambi Batanghari Plantation dengan total luas kebakaran $130 \mathrm{Ha}$ menimbulkan estimasi kebakaran sebesar Rp.6.912.336.000,- (Enam Milyar Sembilan ratus Dua Belas Juta Tiga Ratus Tiga Puluh Enam Ribu Rupiah), PT. Mas Plantion dengan total luas kebakaran $90 \mathrm{Ha}$ menimbulkan estimasi kerugian sebesar Rp.7.017.600.000,- (Tujuh Milyar Tujuh Belas Juta Enam Ratus Ribu Rupiah), PT. Wana Seponjen dengan luas kebakaran 50 Ha menimbulkan estimasi kerugian sebesar Rp.1.754.400.000,- (Satu Milyar Tujuh Ratus Lima Puluh Empat Juta Empat Ratus Ribu Rupiah), dengan total kerugian sebesar Rp.47.945.430.000.- (Empat Puluh Tujuh Milyar Sembilan Ratus Empat Puluh Lima Juta Empat Ratus Tiga Puluh Ribu Rupiah).

Dari uraian tersebut diatas sudah jelas pelaku pembakaran lahan perkebunan semestinya sudah dapat dijatuhkan sanksi administrasi dan dijerat dengan Undang-Undang yang terkait dengan lingkungan dan perlindungan sumber daya alam seperti Undang-Undang Nomor 39 Tahun 2014 tentang Perkebunan, Undang-Undang Nomor 32 Tahun 2009 tentang Perlindungan dan Pengelolaan Lingkungan Hidup dan Undang-Undang Nomor 41 Tahun 1999 tentang Kehutanan Peraturan Pemerintah Nomor 4 Tahun 2001 Tentang Pengendalian Kerusakan dan atau Pencemaran Lingkungan Hidup Yang Berkaitan Dengan Kebakaran Hutan dan atau Lahan.

Pemegang izin usaha perkebunan seperti yang terdapat dalam tabel II di Kabupaten Muaro Jambi dapat dikenai sanksi dalam Undang-Undang ini karena melanggar ketentuan yang telah ditetapkan. Mereka telah diberikan izin oleh pemerintah untuk membuka usaha perkebunan dengan berbagai syarat dan ketentuan yang harus dipenuhi dan tidak boleh untuk dilanggar yaitu tidak menimbulkan kegiatan yang mengakibatkan kerusakan lingkungan. Akan tetapi, pelaku usaha perkebunan masih saja melakukan pembukaan lahan dengan cara membakar untuk penyiapan lahan produksi. Pemerintah selaku pejabat yang berwenang dalam menangani masalah hal ini harus dapat menjatuhkan sanksi yang tegas yaitu berupa penjatuhan sanksi administrasi kepada pelaku pembakaran lahan perkebunan. Adapun sanksi administrasi tersebut adalah:

1. Paksaan pemerintah (bestuursdwang);

2. Penarikan kembali keputusan (ketetapan) yang menguntungkan;

3. Uang paksa (dwangsom); dan

4. Denda administratif.

Penerapan sanksi administrasi merupakan salah satu cara penegakan hukum di bidang kehutanan dan perkebunan yang paling efektif. Karena dalam penerapan sanksi ini tidak melalui proses yang panjang dan berbelit-belit, sebagaimana menggunakan prosedur biasa.

Upaya penegakan sanksi administrasi oleh pemerintah secara konsisten sesuai dengan kewenangan yang ada akan berdampak bagi penegakan hukum terutama dalam rangka menjaga kelestarian fungsi lingkungan hidup. Sehubungan dengan hal ini maka penegakan sanksi administrasi merupakan garda terdepan dalam penegakan hukum lingkungan (primum remedium). Jika sanksi administrasi dinilai tidak efektif barulah dipergunakan sarana sanksi pidana sebagai senjata pamungkas (ultimum remedium).

Junaidi, selaku Kepala Seksi Konservasi dan Rehabilitasi Lahan Dinas Perkebunan Provinsi Jambi menyebutkan:

"Penerapan sanksi terhadap pelaku pembakaran lahan perkebunan sudah berjalan yaitu berupa sanksi pidana, sudah ada yang ditangkap dan sudah ada yang dipenjara. Akibat dari penerapan sanksi tersebut, memberikan efek jera kepada pelaku pembakaran 
hutan dan lahan sehingga dapat menekan angka kebakaran lahan setiap tahunnya. Untuk Kabupaten Muaro Jambi pelaku kebakaran hutan dan lahan yang dilakukan oleh beberapa perusahaan sampai saat ini masih dalam proses penyidikan di Polda Jambi". 4

Dari pernyataan tersebut dapat dilihat bahwa Penegakan hukum dari masalah kebakaran lahan perkebunan lebih banyak diterapkan sanksi pidana. Seiring dengan Junaidi, Syakur selaku Kepala Seksi Perlindungan Hutan dan Penyuluhan Dinas Kehutanan dan Perkebunan Kabupaten Muaro Jambi, menyebutkan:

"Untuk penerapan sanksi administrasi terhadap pembakaran lahan perkebunan baik badan hukum maupun masyarakat belum pernah diterapkan oleh pemerintah Kabupaten Muaro Jambi, karena terhambat masalah kewenangan. Kewenangan untuk menerapkan sanksi administrasi merupakan kewenangan Pemerintah Provinsi dan kami hanya berwenang di dalam kawasan hutan dan diluar kawasan hutan bukan termasuk kewenangan kami". 5

Undang-Undang Nomor 32 Tahun 2004 tentang Pemerintahan Daerah telah dicabut dan digantikan dengan undang-undang baru yakni Undang-Undang Nomor 23 Tahun 2014. Salah satu perubahan yang mendasar dari undang-undangtersebut yaitu pembagian urusan antara pemerintah pusat, pemerintah daerah provinsi dan pemerintah daerah kabupaten/kota. Perubahan yang terjadi adalah rincian detil pembagian bidang urusan pemerintahan yang semula diatur dalam lampiran Peraturan Pemerintah Nomor 38 Tahun 2007 kini menjadi bagian dari lampiran Undang-Undang Nomor 23 Tahun 2014. Dengan demikian maka pembagian urusan yang telah ditetapkan dalam Undang-Undang Nomor 23 Tahun 2014 tidak bisa dikesampingkan atau dikecualikan oleh undang-undang sektoral lainnya. Salah satu perubahan substansi bidang urusan pemerintahan yaitu pada sektor kehutanan yang semula dibagi antara pemerintah pusat, pemerintah daerah provinsi dan pemerintah daerah kabupaten/kota. Kini hanya diberikan kepada pemerintah pusat dan pemerintah daerah provinsi, sehingga wilayah kerja provinsi bertambah luas yaitu mencakup seluruh wilayah kabupaten/kota. Penyelenggaraan urusan pemerintahan tersebut yaitu bidang kehutanan, kelautan, serta energi dan sumber daya mineral yang dibagi antara pemerintah pusat dan daerah provinsi. Daerah kabupaten/kota penghasil dan bukan penghasil mendapatkan bagi hasil dari penyelenggaraan urusan pemerintahan tersebut. Meskipun dilimpahkan ke pemerintah daerah provinsi namun dalam pelaksanaannya pemerintah derah provinsi dapat diselenggarakan dengan cara melakukannya sendiri; dengan cara menugasi daerah kabupaten/kota berdasarkan asas tugas pembantuan atau; dengan cara menugasi desa. Adapun kewenangan pemerintah daerah kabupaten/kota hanya ada pengelolaan TAHURA. Sementara rincian urusan pemerintahan bidang kehutanan yang menjadi kewenangan daerah provinsi adalah sebagai berikut:

1. Pelaksanaan tata hutan kesatuan pengelolaan hutan kecuali pada kesatuan pengelolaan hutan konservasi (KPHK).

2. Pelaksanaan rencana pengelolaan kesatuan pengelolaan hutan kecuali KPHK.

3. Pelaksanaan pemanfaatan hutan di kawasan hutan produksi dan hutan lindung, meliputi pemanfaatan kawasan hutan, pemanfaatan hasil hutan bukan kayu, pemungutan hasil hutan, pemanfaatan jasa lingkungan kecuali pemanfaatan penyimpanan dan/atau penyerapan karbon.

4. Pelaksanaan rehabilitasi di luar kawasan hutan negara.

${ }^{4}$ Wawancara dengan Junaidi, Kepala Seksi Konservasi dan Rehabilitasi Lahan Dinas Perkebunan Provinsi Jambi

${ }^{5}$ Wawancara dengan Syakur, Kepala Seksi Perlindungan Hutan dan Penyuluhan Dinas Kehutanan dan Perkebunan Kabupaten Muaro Jambi. 
5. Pelaksaana perlindungan hutan di hutan lindung, dan hutan produksi.

6. Pelaksanaan pengolahan hasil hutan bukan kayu. Pelaksanaan pengolahan hasil hutan kayu dengan kapasitas produksi $<6000 \mathrm{~m}^{3}$ per tahun.

7. Pelaksanaan pengelolaan kawasan hutan dengan tujuan khusus (KHDTK) untuk kepentingan religi.

8. Pelaksaan perlindungan, pengawetan dan pemanfaatan secara lestari taman hutan raya (TAHURA) lintas kabupaten/kota.

9. Pelaksanaan perlindungan tumbuhan dan satwa liar yang tidak dilindungi dan/atau tidak masuk dalam lampiran (Appendix CITIES).

10. Pelaksandan kawasan aan pengelolaan kawasan bernilai ekosistem penting dan daerah penyangga kawasan suaka alam dan kawasan pelestarian alam.

11. Pelaksanaan penyuluhan kehutanan provinsi.

12. Pemberdayaan masyarakat di bidang kehutanan.

13. Pelaksanaan pengelolaan daerah aliran sungai (DAS) lintas daerah kabupaten/kota dan dalam daerah kabupaten/kota dalam 1 daerah provinsi.

Berdasarkan Undang-Undang Nomor 23 Tahun 2014, perlindungan hutan di hutan lindung dan hutan produksi bukan lagi menjadi kewenangan daerah kabupaten/kota melainkan menjadi kewenangan daerah provinsi. Sebagaimana tercantum pada lampiran Undang-Undang Nomor 23 Tahun 2014. Untuk itu, dalam pelaksanaan perlindungan hutan di tingkat kabupaten/kota pemerintah daerah provinsi Sulawesi Selatan menyelenggarakannya dengan cara menugasi daerah kabupaten/kota berdasarkan asas tugas pembantuan. ${ }^{81}$ Sehingga akan dibentuk Unit Pelaksana Teknis (UPT) berkaitan dengan perlindungan hutan lindung di tingkat kabupaten/kota. UPT tersebut langsung dibawahi oleh Dinas Kehutanan Provinsi serta bertanggung jawab kepada Dinas Kehutanan Provinsi.

\section{Upaya Penanggulangan Akibat Kebakaran Hutan dan Lahan Perkebunan oleh Badan Hukum Perdata di Kabupaten Muaro Jambi}

Undang-Undang Nomor 32 Tahun 2004 tentang Pemerintahan Daerah telah dicabut dan digantikan dengan undang-undang baru yakni Undang-Undang Nomor 23 Tahun 2014. Salah satu perubahan yang mendasar dari undang-undang tersebut yaitu pembagian urusan antara pemerintah pusat, pemerintah daerah provinsi dan pemerintah daerah kabupaten/kota. Perubahan yang terjadi adalah rincian detil pembagian bidang urusan pemerintahan yang semula diatur dalam lampiran Peraturan Pemerintah Nomor 38 Tahun 2007 kini menjadi bagian dari lampiran Undang-Undang Nomor 23 Tahun 2014. Dengan demikian maka pembagian urusan yang telah ditetapkan dalam Undang-Undang Nomor 23 Tahun 2014 tidak bisa dikesampingkan atau dikecualikan oleh undang-undang sektoral lainnya. Salah satu perubahan substansi bidang urusan pemerintahan yaitu pada sektor kehutanan yang semula dibagi antara pemerintah pusat, pemerintah daerah provinsi dan pemerintah daerah kabupaten/kota. Kini hanya diberikan kepada pemerintah pusat dan pemerintah daerah provinsi, sehingga wilayah kerja provinsi bertambah luas yaitu mencakup seluruh wilayah kabupaten/kota. Penyelenggaraan urusan pemerintahan tersebut yaitu bidang kehutanan, kelautan, serta energi dan sumber daya mineral yang dibagi antara pemerintah pusat dan daerah provinsi. Daerah kabupaten/kota penghasil dan bukan penghasil mendapatkan bagi hasil dari penyelenggaraan urusan pemerintahan tersebut. Meskipun dilimpahkan ke pemerintah daerah provinsi namun dalam pelaksanaannya pemerintah daerah provinsi dapat diselenggarakan dengan cara melakukannya sendiri; dengan cara menugasi daerah kabupaten/kota berdasarkan asas tugas pembantuan atau; dengan cara menugasi desa. Adapun kewenangan pemerintah daerah Kabupaten/kota hanya pada pengelolaan TAHURA. 
Sementara rincian urusan pemerintahan bidang kehutanan yang menjadi kewenangan daerah provinsi adalah sebagai berikut:

a. Pelaksanaan tata hutan kesatuan pengelolaan hutan kecuali pada kesatuan pengelolaan hutan konservasi (KPHK).

b. Pelaksanaan rencana pengelolaan kesatuan pengelolaan hutan kecuali KPHK.

c. Pelaksanaan pemanfaatan hutan di kawasan hutan produksi dan hutan lindung, meliputi pemanfaatan kawasan hutan, pemanfaatan hasil hutan bukan kayu, pemungutan hasil hutan, pemanfaatan jasa lingkungan kecuali pemanfaatan penyimpanan dan/atau penyerapan karbon.

d. Pelaksanaan rehabilitasi di luar kawasan hutan negara.

e. Pelaksaana perlindungan hutan di hutan lindung, dan hutan produksi.

f. Pelaksanaan pengolahan hasil hutan buka dan kayu. Pelaksanaan pengolahan hasil hutan kayu dengan kapasitas produksi $<6000 \mathrm{~m}^{3}$ per tahun.

g. Pelaksanaan pengelolaan kawasan hutan dengan tujuan khusus (KHDTK) untuk kepentingan religi.

h. Pelaksaan perlindungan, pengawetan dan pemanfaatan secara lestari taman hutan raya (TAHURA) lintas kabupaten/kota.

i. Pelaksanaan perlindungan tumbuhan dan satwa liar yang tidak dilindungi dan/atau tidak masuk dalam lampiran (Appendix CITIES).

j. Pelaksandan kawasan aan pengelolaan kawasan bernilai ekosistem penting dan daerah penyangga kawasan suaka alam dan kawasan pelestarian alam.

k. Pelaksanaan penyuluhan kehutanan provinsi.

1. Pemberdayaan masyarakat di bidang kehutanan.

m. Pelaksanaan pengelolaan daerah aliran sungai (DAS) lintas daerah kabupaten/kota dan dalam daerah kabupaten/kota dalam 1 daerah provinsi.

Berdasarkan Undang-Undang Nomor 23 Tahun 2014, perlindungan hutan di hutan lindung dan hutan produksi bukan lagi menjadi kewenangan daerah kabupaten/kota melainkan menjadi kewenangan daerah provinsi. Sebagaimana tercantum pada lampiran Undang-Undang Nomor 23 Tahun 2014. Apabila kendala-kendala yang ditemui dalam penerapan sanksi administrasi tidak segera ditanggulangi, maka bukan tidak mungkin kebakaran lahan perkebunan di Kabupaten Muaro Jambi akan semakin meningkat setiap tahunnya dan ketentuan peraturan perundang-undangan yang mengatur tentang larangan membuka lahan dengan cara membakar tidak akan terlaksana atau hanya dijadikan lambang belaka.

Adapun dalam mengatasi kendala-kendala yang ditemui dalam penerapan sanksi administrasi terhadap pembakaran lahan perkebunan kelapa sawit oleh badan hukum perdata maka upaya penanggulangan yang ditempuh oleh pemerintah Kabupaten Muaro Jambi, seperti yang dikatakan oleh bapak Syakur, upaya penanggulangan yang dilakukan sebagai berikut:

1. Dengan meminta bantuan kepada Badan Penanggulangan Bencana Daerah untuk membantu memadamkan api yang berada di luar kawasan hutan dan untuk di dalam kawasan hutan dengan bantuan dari manggala agni.

2. Sosialisasi dengan membentuk regu pemadam yang disediakan oleh perusahaan perkebunan. ${ }^{6}$

Kemudian menurut Jamhur, selaku Sekretaris Kepala Dinas Kehutanan dan Perkebunan Kabupaten Muaro jambi mengatakan:

\footnotetext{
${ }^{6}$ Wawancara, dengan Syakur, Kepala Seksi Perlindungan Hutan dan Penyuluhan Dinas Kehutanan dan Perkebunan Kabupaten Muaro Jambi.
} 
"Sesuai dengan Pedoman Pengendalian Kebakaran Lahan dan Kebun yang diterbitkan oleh Direktorat Perlindungan Perkebunan Direktorat Jenderal Perkebunan Kementerian Pertanian Tahun 2010, maka kami melakukan sosialisasi dengan perusahaan dan masyarakat untuk melakukan pengendalian kebakaran dengan melalui beberapa komponen, yaitu: pertama, Pencegahan terhadap terjadinya kebakaran; kedua, Pemadaman kebakaran dengan sesegera mungkin sewaktu api masih kecil; ketiga, Penanganan pasca kebakaran dalam rangka pemulihan. Selanjutnya, pencegahan kebakaran di bidang perkebunan dapat dilakukan melalui pendekatan pengelolaan lahan dan kebun yang mencakup tahap penyiapan lahan, pemeliharaan, panen dan pasca panen'?

Selanjutnya Junaidi selaku Kepala Seksi Konservasi dan Rehabilitasi Lahan Dinas Perkebunan Provinsi Jambi menyebutkan;

"Upaya yang dilakukan untuk menanggulangi kebakaran lahan perkebunan yaitu kami mengarahkan perusahaan perkebunan untuk melengkapi sarana dan prasarana pengendalian kebakaran lahan dan kebun serta dengan meminta bantuan kepada anggota manggala agni apabila kebakaran meluas dan tidak dapat dikendalikan. Selanjutnya memberikan himbauan agar tidak membuka lahan dengan cara membakar sebagaimana yang diatur dalam Peraturan Menteri Pertanian Nomor 47 Tahun 2014, memberikan teguran kepada perusahaan yang membuka lahan dengan cara membakar dan upaya yang terakhir yaitu dengan memberikan sanksi yang tegas". 8

Salah satu perubahan dari Undang-Undang Nomor 23 Tahun 2014 dari undang-undang sebelumnya adalah tentang pembagian urusan pemerintahan antara pemerintah pusat, pemerintah daerah provinsi, dan pemerintah daerah kabupaten/kota. Pembagian urusan pemerintahan tersebut diatur dalam lampiran undang-undang yang memberikan status otonomi yang lebih kuat kepada daerah. Sehingga terhindar dari tumpang tindih dan ketidakpastian kewenangan antar tingkatan/susunan pemerintahan yang akan memberikan keseimbangan pada beban urusan berdasarkan kriteria dan prinsip pembagian urusan pemerintahan yang sudah ada.

Hal yang perlu dicermati lebih lanjut adalah masalah penegakan hukum, mengingat kebakaran hutan dan lahan yang selalu berulang sedangkan instrumen hukum yang ada telah lengkap. Penegakan hukum dipengaruhi oleh 5 faktor baik faktor tersebut berdampak positif atau negatif. Faktor yang dimaksud adalah faktor hukum itu sendiri; faktor penegak hukum, yakni pihak-pihak yang membentuk maupun yang menerapkan; faktor sarana atau fasilitas yang mendukung penegakan hukum; faktor masyarakat, lingkungan dimana hukum tersebut berlaku atau diterapkan; dan faktor kebudayaan.

Dalam kasus kebakaran hutan, lahan dan kabut asap dengan instrumen hukum yang sudah lengkap maka penegakan hukum atas kebakaran hutan dan lahan yang berulang, kemungkinan besar dipengaruhi oleh faktor penegakan hukum yang lain seperti kelembagaan, terutama pemerintah pusat dan daerah, sarana dan fasilitas penanggulangan kebakaran hutan, faktor masyarakat yang diharapkan tidak menjadi penyebab kebakaran, serta faktor aparatur penegakan hukum.

\footnotetext{
${ }^{7}$ Wawancara dengan Jamhur, Sekretaris Kepala Dinas Kehutanan dan Perkebunan Kabupaten Muaro Jambi,.

${ }^{8}$ Wawancara dengan Junaidi, Kepala Seksi Konservasi dan Rehabilitasi Lahan Dinas Perkebunan Provinsi Jambi.
} 


\section{KESIMPULAN DAN SARAN}

\subsection{Kesimpulan}

Berdasarkan Undang-Undang Nomor 23 Tahun 2014, perlindungan hutan di hutan lindung dan hutan produksi bukan lagi menjadi kewenangan daerah kabupaten/kota melainkan menjadi kewenangan daerah provinsi. Sebagaimana tercantum pada lampiran UndangUndang Nomor 23 Tahun 2014. Untuk itu, dalam pelaksanaan perlindungan hutan di tingkat kabupaten/kota pemerintah daerah provinsi Sulawesi Selatan menyelenggarakannya dengan cara menugasi daerah kabupaten/kota berdasarkan asas tugas pembantuan. Sehingga akan dibentuk Unit Pelaksana Teknis (UPT) berkaitan dengan perlindungan hutan lindung di tingkat kabupaten/kota. UPT tersebut langsung dibawahi oleh Dinas Kehutanan Provinsi serta bertanggung jawab kepada Dinas Kehutanan Provinsi. Penerapan sanksi administrasi merupakan salah satu cara penegakan hukum di bidang kehutanan dan perkebunan yang paling efektif. Karena dalam penerapan sanksi ini tidak melalui proses yang panjang dan berbelit-belit, sebagaimana menggunakan prosedur biasa. Upaya penegakan sanksi administrasi oleh pemerintah secara konsisten sesuai dengan kewenangan yang ada akan berdampak bagi penegakan hukum terutama dalam rangka menjaga kelestarian fungsi lingkungan hidup. Sehubungan dengan hal ini maka penegakan sanksi administrasi merupakan garda terdepan dalam penegakan hukum lingkungan (primum remedium). Jika sanksi administrasi dinilai tidak efektif barulah dipergunakan sarana sanksi pidana sebagai senjata pamungkas (ultimum remedium).

Dalam kasus kebakaran hutan, lahan dan kabut asap dengan instrumen hukum yang sudah lengkap maka penegakan hukum atas kebakaran hutan dan lahan yang berulang, kemungkinan besar dipengaruhi oleh faktor penegakan hukum yang lain seperti kelembagaan, terutama pemerintah pusat dan daerah, sarana dan fasilitas penanggulangan kebakaran hutan, faktor masyarakat yang diharapkan tidak menjadi penyebab kebakaran, serta faktor aparatur penegakan hukum. Apabila kendala-kendala yang ditemui dalam penerapan sanksi administrasi tidak segera ditanggulangi, maka bukan tidak mungkin kebakaran lahan perkebunan di Kabupaten Muaro Jambi akan semakin meningkat setiap tahunnya dan ketentuan peraturan perundang-undangan yang mengatur tentang larangan membuka lahan dengan cara membakar tidak akan terlaksana atau hanya dijadikan lambang belaka. Untuk mengatasi kendala-kendala yang ditemui dalam penerapan sanksi administrasi terhadap pembakaran lahan perkebunan kelapa sawit oleh badan hukum perdata maka upaya penanggulangan yang ditempuh oleh pemerintah Kabupaten Muaro Jambi, Dengan meminta bantuan kepada Badan Penanggulangan Bencana Daerah untuk membantu memadamkan api yang berada di luar kawasan hutan dan untuk di dalam kawasan hutan dengan bantuan dari manggala agnidan Sosialisasi dengan membentuk regu pemadam yang disediakan oleh perusahaan perkebunan.

\subsection{Saran}

a. Diharapkan Pemerintah daerah provinsi dan pemerintah daerah kabupaten perlu melakukan upaya perlindungan hutan tambahan ketika tidak adanya personil polisi hutan selama pengalihan P3D, seperti mengupayakan TNI, satpol PP, dan kepolisian setempat. Sehingga dapat mengurangi kegiatan perambahan dan penebangan liar.

b. Perlunya penyuluhan hukum terutama mengenai hukum kehutanan kepada masyarakat sehingga masyarakat mengetahui peraturan yang mengatur perlindungan hutan akibat kebakaran hutan dan lahan oleh badan hukum perdata.

c. diharapkan Pemerintah Provinsi sesuai dengan kewenangannya berdasarkan UU 23 Tahun 2004 tentang Pemerintahan Daerah dapat menerapkan sanksi administrasi yang tegas 
terhadap pelaku pembakaran lahan perkebunan. Serta peran Pemerintah Kabupaten Muaro Jambi dapat memperkuat kelembagaan dan peraturan perundang-undangan yang mendukung pembukaan lahan tanpa bakar (zero burning), pencegahan kebakaran hutan dan lahan, serta pencemaran kabut asap sehingga langkah hukum yang diharapkan dapat menjangkau para pelaku pembakaran lahan dan hutan yang selama ini memberikan dampak buruk secara sosial dan ekonomi kepada negara.

\section{DAFTAR PUSTAKA}

\section{Buku}

Adrian Sutedi, Hukum Perizinan dalam sektor Pelayanan Publik, Sinar Grafika, Jakarta, 2010.

Bahder Johan Nasution, Metode penelitian Ilmu Hukum, CV. Mandar Maju, Bandung, 2008.

Helmi, Hukum Perizinan Lingkungan Hidup, Sinar Grafika, Jakarta, 2012.

Muladi dan Dwidja Priyatno, Pertanggungjawaban Pidana Korporasi, Kencana, 2010.

Philipus M. Hadjon, et. al, Pengantar Hukum Administrasi Indonesia, Gadjah Mada

University Press, Yogyakarta, 1993.

Ridwan HR, Hukum Administrasi Negara, Cetakan ke-11, Rajawali Pers, Jakarta, 2014.

Salim, Dasar-Dasar Hukum Kehutanan, Cetakan Kelima, Sinar Grafika, Jakarta, 2013.

Soerjono Soekanto, Faktor-Faktor yang mempengaruhi Penegakan Hukum, Cetakan ke-14,

Rajawali Press, Jakarta, 2014. Penegakan Hukum, Bina Cipta, jakarta, 1983.

Takdir Rahmadi, Hukum lingkungan Indonesia, Raja Grafindo Persada, jakarta, 2012.

\section{JURNAL/KARYA ILMIAH}

Inosentius Samsul, "Instrumen Hukum Penanggulangan Kebakaran Hutan, Lahan, Dan Polusi Asap”, Info Singkat, Vol. VII, No. 17/I/P3DI/September/2015.

Kementerian Pertanian Direktorat Jenderal Perkebunan, "Pengawasan dan upaya pengendalian perizinan usaha perkebunan”, Jakarta, 2014.

Novan Setiawan, "Penerapan Sanksi Administrasi Terhadap Pembakaran Hutan di Kabupaten Muaro Jambi", Skripsi Sarjana Hukum Universitas Jambi, Jambi, 2005.

\section{Peraturan Perundang-undangan}

Republik Indonesia, Undang-Undang Dasar Negara Republik Indonesia Tahun 1945. , Undang-undang Nomor 41 Tahun 1999 Tentang Kehutanan , Undang-undang Nomor 32 Tahun 2009 Tentang Perlindungan dan Pengelolaan Ligkungan Hidup , Undang-undang Nomor 23 Tahun 2014 Tentang Pemerintah Daerah , Undang-Undang Nomor 39 Tahun 2014 Tentang Perkebunan , Peraturan Menteri Kehutanan Nomor: P. 12/Menhut-Ii/2009 Tentang

Pengendalian Kebakaran Hutan

\section{Internet}

http://trishadennis.blogspot.co.id/2012/10/kebakaran-hutan.html

http://andre4088.blogspot.co.id/2012/08/tipe-tipe-kebakaran-shutan.html 